\title{
GARNETS OF MICA-SCHISTS FROM CRNI VRH AND RESAVSKI HUMOVI (SERBIA)
}

\section{S.Erić, D.Milovanović and D.Babič}

Department of Mineralogy and Petrology, Faculty of Mining and Geology, Belgrade University, Serbia and Montenegro, suzanaeric@yahoo.com

\begin{abstract}
Metamorphic rocks of the Crni Vrh and Resavski Humovi area belong to the north-northwestern part of the Serbo-Macedonian Composite Terrane and consist of different types of mica-schists, gneisses and amphibolites.

Mica-schists are composed of biotite, muscovite, garnet, staurolite, kyanite, small quantity of Kfeldspar, acid plagioclase and quartz. Accessory minerals are apatite, zircon, tourmaline and ilmenite.

Garnets in mica-schists from both localities occur as subhedral to anhedral porphyroblasts from 0.2 to $10 \mathrm{~mm}$ in size. Most garnets are oriented parallel to the dominant foliation.

Garnets from the Crni Vrh mica-schists contain more spesartine component than garnets from Resavski Humovi, while almandine component show opposite tendency. The difference between those garnets is clearly visible, as well as zonality expressed through the increase of almandine component from center to the grain rim. The spesartine component as mentioned above, shows the opposite tendency.

Using different geothermometers and geobarometers it was found that mica-schists from Crni Vrh were formed at temperatures from $550-600^{\circ} \mathrm{C}$ and pressures from $6-6.2 \mathrm{kbar}$, while micaschists from Resavski Humovi developed at slightly lower temperatures $\left(520-560^{\circ} \mathrm{C}\right)$ and at some higher pressures (7-7.3 kbar).
\end{abstract}

\section{INTRODUCTION}

Garnet is an important mineral in the study of metamorphic processes because individual crystals preserve a record of the metamorphic and deformational environment of the rock during one or more tectonic events. Metamorphosed metapelites also provide useful information, as pelitic bulk composition is generally mineralogical sensitive to changes in pressure and temperature. Investigated mica-schists with garnets belong to metamorphic rocks of the Serbo-Macedonian Composite Terrane (SMMT) (Karamata and Krstić, 1996) which are composed of different types of gneisses, mica-schists, amphibolites and rarely marbles. Migmatites and rare eclogites occur along the eastern margin of this unit.

Metamorphic rocks of the SMMT show nearly ubiquitous amphibolite-facies metamorphic assemblage and are interpreted as products of prograde Variscan metamorphism.

KJAr radiometric age determinations on hornblende $\left(270^{+} /-10 \mathrm{Ma}\right)$ indicate that the major metamorphic phase occurred during Variscan age, whereas the K/Ar ages of biotite, $\left(120 \mathrm{Ma}^{+} /-10 \mathrm{Ma}\right)$, muscovite and feldspar are probably related to Alpine tectonic events.

\section{GEOLOGY}

Metamorphic rocks cf the Crni Vrh and Resavski Humovi area belong to the north-northwestern part of the SMMT (Fig. 1) and consist of different types of mica-schists, gneisses, and amphibolites. These rocks represent a metamorphosed flysch-like "series", cut by various igneous rocks. 


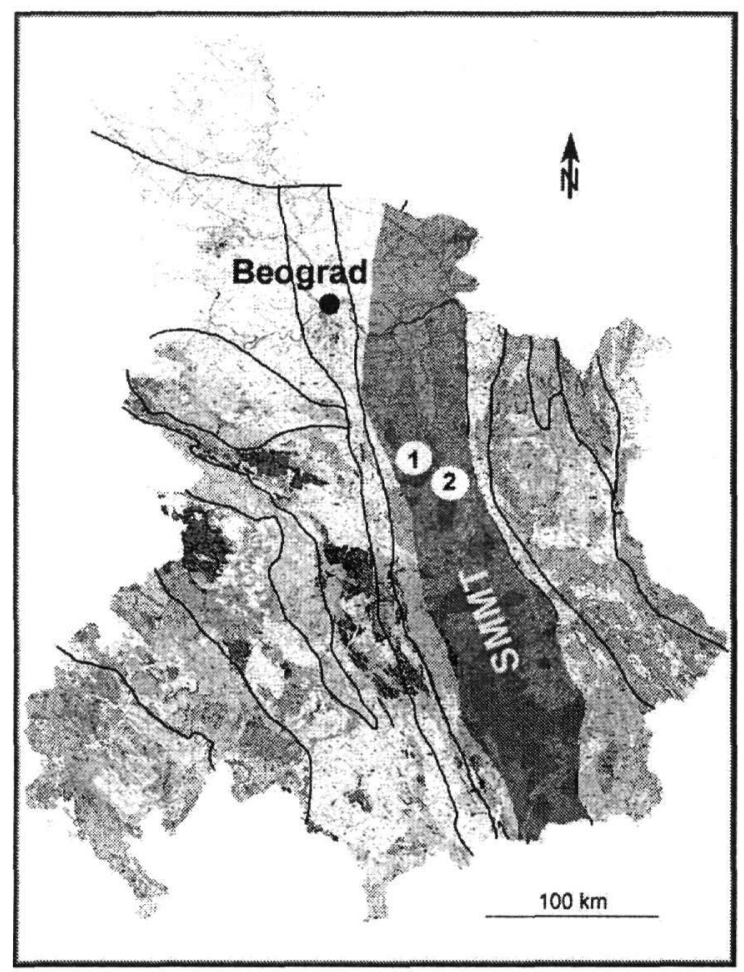

Figure 1. Position of mica-schits from the Crni Vrh (1) and Resavski Humovi (2) in Serbo-Macedonian CompositeTerrane (Karamata and Krstić, 1996)

Mica-schists of the Crni Vrh occur 10km north of Bagrdan on the road between the villages Strižilo and Donja Komarica, along Pišljak and Kusača streams. Mica-schists of the Resavski humovi are located $15 \mathrm{~km}$ southwest of Svilajnac and $2 \mathrm{~km}$ of Miljkov monestery.

These rocks are me ijum to coarse grained, showing migmatitic features such as stromatic and stictolithic structures with rare intercalations of amphibolite, marble and quartzite. Isolated rootless, mostly isoclinal folds of $\mathrm{cm}$-scale quartz veins and isoclinal folds in quartzitic or feldspar-rich layers are parallel with the main schistosity and point an early deformation event. The mica-schists sometimes gradually pass into to gneisses and migmatites. When abundance and size of the K-feldspar pophyroblasts increase feldspatic to quartzo-feldspatic streams occur. These rocks show a pervasive high grade $S_{1}$ foliation that is overprinted by a slightly to strongly discordant $S_{2}$ foliation. Locally crenulation cleavage grades into a continuous schistosity by a process of progressive transposition and recrystallization.

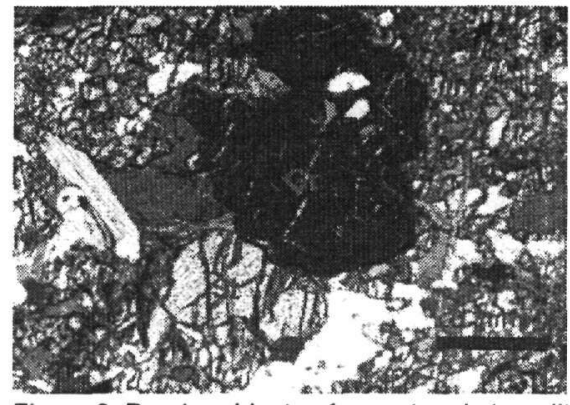

Figure 2. Porphyroblasts of garnet and staurolite

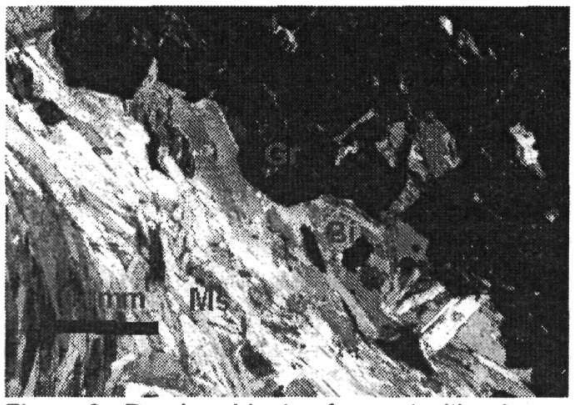

Figure 3. Porphyroblasts of garnet with micas 


\section{PETROGRAPHY}

Mica-schists are composed of biotite, muscovite, garnet, staurolite, kyanite, small quantity of Kfeldspar, (orthoclase and microcline), acid plagioclase, and quartz. Accessory minerals are apatite, zircon, tourmaline and sphene.

The texture of mica-schists is lepidoblastic, granoblastic and porphyroblastic with variable size of minerals, from a few , $\mathrm{nm}$ to a few $\mathrm{cm}$. Biotite and muscovite make up to $50 \%$ vol of these rocks (Table 1).

Biotite and muscovite vary in lengths from 0.1 to $2 \mathrm{~cm}$ and show a strong shape preferred orientation defining schistosity in mica-schists. Three generations of micas are visible: deformed flakes up to $2 \mathrm{~cm}$ in size, which are most probably relics of the clasts protolith; a second generation, in the matrix, is fine to medium grained, synkinematic, and finally youngest postkinematic generation are represented by fine flakes randomly oriented, which cut the earlier genertations. An anastoming cofiguration of biotite and muscovite around large garnet porphyroblasts indicates that the formation of the dominant schistosity postdated garnet growth.

Biotite and muscovite also occur as inclusions in garnet and staurolite porphyroblasts. Biotite is usually replaced with chlorite and fine grained Fe-oxides.

Table 1. Mineral assemblages and modal composition of the mica-schists from the Crni Vrh and Resavski Humovi

\begin{tabular}{ll}
\hline Crni Vrh & Resavski Humovi \\
\hline $\mathrm{Qz}(13 \%)+\mathrm{Ms}(44 \%)+\mathrm{Bi}(11 \%)+\mathrm{Gt}(18 \%)+\mathrm{Pl}(3 \%)$ & $\mathrm{Qz}(20 \%)+\mathrm{Ms}(41 \%)+\mathrm{Bi}(13 \%)+\mathrm{Gt}(16 \%)+\mathrm{St}(5 \%)+$ \\
$+\mathrm{Kf}+\mathrm{St}(10 \%)+\mathrm{Tour}+\mathrm{Chl}+\mathrm{Ru}+\mathrm{Im}$ & $\mathrm{Ky}(2 \%)+\mathrm{Pl}(2 \%)+\mathrm{Kf}+\mathrm{Tour}+\mathrm{Ru}+\| \mathrm{m}$ \\
\hline
\end{tabular}

Garnet shows variols textures. It occur as subhedral to anhedral porphyroblasts (Fig. 2; Fig. 3) from 0.2 to $10 \mathrm{~mm}$ in size, sometimes partially replaced by aggregates of chlorite and biotite. Garnet usually contains sigmoidal to spiral inclusion of quartz, micas and ilmenite, suggesting a syncinematic crystallization or intertectonic growth over preexisting crenulation cleavage. Some garnets contain inclusions only in their interior part. Most garnets are oriented parallel to the dominant foliation. Small crystals of garnet occur in strings along foliation planes in many samples which suggests a pre to syn-kinematic crystallization. Some garnets are undeformed and clearly post-date penetrative deformation.

Staurolite in mica-schist from the Crni Vrh occurs in impressive size porphyroblasts (up to $10 \mathrm{~cm}$ in diameter) and contaiı inclusions of garnet, micas (mainly biotite) quartz and ilmenite which locally comprise $10 \%$ or more of the porphyroblasts.

Quartz exhibit undulatory extinction and occurs as an interpenetrative mosaic of equal grains, up to $1 \mathrm{~mm}$ in size that define ribbons parallel to foliation. This mineral is abundant both as matrix and inclusions in garnet. In the ribbons quartz sometimes displays coarser grain size, straight grain boundaries and triple junctions that indicate grain growth processes driven by reaction of interfacial free energy. Quartz also occurs as recrystallized grains in the pressure shadows around grains of garnets.

K-feldspar is rare, occurring either as subhedral or anhedral grains in the matrix, usually associated with quartz.

\section{CHEMISTRY}

The petrographic study of these metamorphic rocks has been supplemented by electron microprobe analysis of their main minerals. Major element analyses were obtained for garnet, staurolite, biotite, muscovite and K-feldspar in the Laboratory of Mineralogy in Hamburg (Germany) and in the Laboratory of Mineralogy, at the Aristotle University of Thessaloniki (Greece). Representative compositional data are available from the authors on request.

About 50 mineral analyses of garnets were carried out and structural formulas were calculated.

Garnets from the Crni Vrh mica-schists contain more spesartine component than garnets from the Resavski humovi, while almandine component shows the opposite tendency. Difference between these garnets is clearly visible in Fig. 4, as well as zonality expressed through the increase of 
almandine component from the center to the grain rim. The spesartine component as mentioned above, shows the opposite tendency.

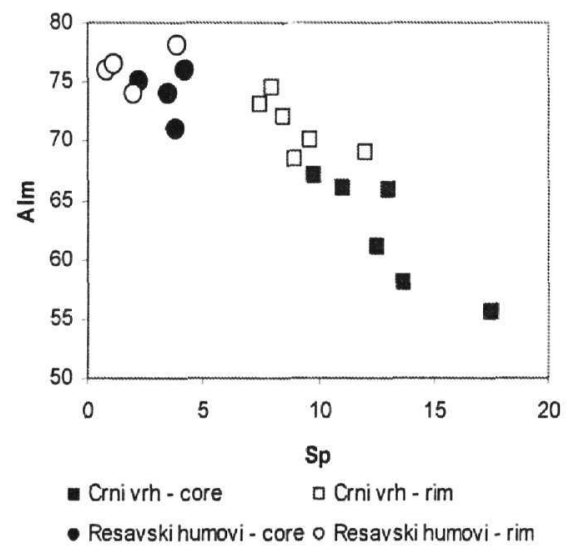

Figure 4. Relation of almandine and spesartine component in garnets

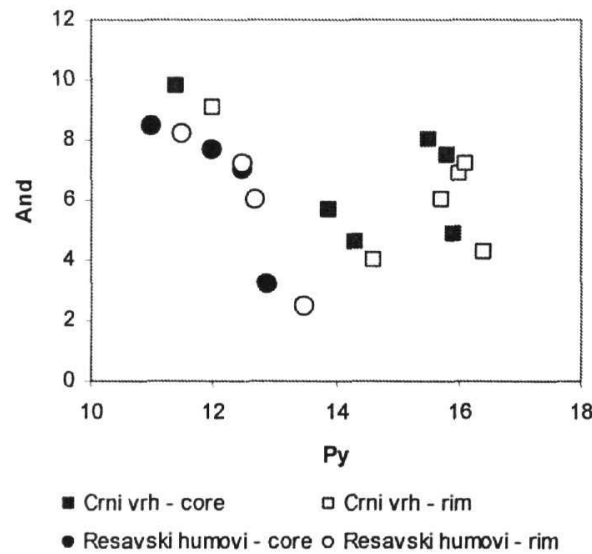

Figure 5. Relation of pyrope and andradite component in garnets

\section{X-RAY ANALYSIS}

Concerning the chemistry of the analyzed garnets higher values for unit cell parameters (Table 2) have been expected for garnets in mica-schists from Crni Vrh (with more spessartine and lower almandine content) than for those in mica-schists from the Resavski Humovi. However, a completely opposite trend was noted. According to well known fact that garnet unit cell increases from pyrope toward andradite, this anomaly should be attributed to higher pyrope (Fig. 5) and lower andradite content in the former than in the latter one.

Table 2. Unit cell parameters of garnet from investigated mica-schists

\begin{tabular}{ll}
\hline $\begin{array}{l}\text { Unit cell parameters of garnets from } \\
\text { Crni Vrh }\end{array}$ & $\begin{array}{l}\text { Unit cell parameters of garnets from } \\
\text { Resavski Humovi }\end{array}$ \\
\hline$a_{0}=11.558(2) A_{;} V_{0}=1543.9(8) \AA^{3}$ & $a_{0}=11.571(2) \AA ; V_{0}=1549.3(7) \AA^{3}$ \\
$a_{0}=11.552(2) \AA ; V_{0}=1541.6(7) \AA^{3}$ & $a_{0}=11.568(2) A ; V_{0}=1547.9(8) \AA^{3}$ \\
& $a_{0}=11.5823(8) A ; V_{0}=1553.7$ (3) $\AA^{3}$ \\
\hline
\end{tabular}

\section{GEOTHERMOMETRY AND GEOBAROMETRY}

Samples for thermobarometry were selected on the basis of petrographic criteria suggesting equilibrium in millimeter scale. Mineral assemblages were compared with petrogenetic grid and chemical compositions of minerals and were used to calculate temperature and pressure using published calibrations of exchange equilibria. Several geothermometers and geobarometers have been used to determine P-T conditions (Fig. 6) during formation and evolution of the investigated mica-schists (Table 3). 
Table 3. Calculated temperatures and pressures of the metamorphism of the mica-schists from Crni Vrh and Resavski Humovi on basis of different methods

\begin{tabular}{lll}
\hline Methods & $\begin{array}{l}\text { Mica-schists from } \\
\text { Crni Vrh }\end{array}$ & $\begin{array}{l}\text { Mica-schists from Resavski } \\
\text { Humovi }\end{array}$ \\
\hline Ferry and Spear, 1978 & $\mathrm{T}\left({ }^{\circ} \mathrm{C}\right)$ & $\mathrm{T}\left({ }^{\circ} \mathrm{C}\right)$ \\
Hodges and Spear, 1982 & $577-581$ & $518-528$ \\
Perchuk and Lavrentova, 1983 & $603-625$ & $554-564$ \\
Ganguly and Saxena, 1984 & $599-610$ & $564-574$ \\
Indares and Martignole 1985 & $583-598$ & $527-567$ \\
Hynes and Forest, 1988 & $559-596$ & $512-522$ \\
Gessman at. al., 1997 & $590-602$ & $544-559$ \\
& $521-539$ & $486-502$ \\
Powell and Holand, 1988 & $\mathrm{P}(\mathrm{kbar})$ & $\mathrm{P}(\mathrm{kbar})$ \\
\hline
\end{tabular}

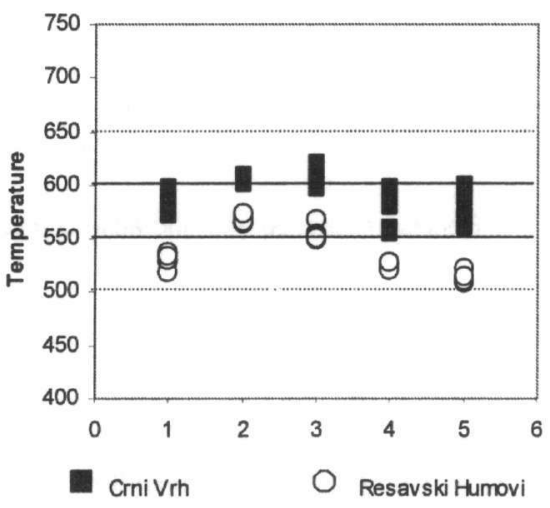

Figure 6. Calculated temperatures of metamorphism of the mica-schists from the Crni Vrh and Resavski Humovi

1-Ferry and Spear, 1978, 2-Perchuk and Lavrentova, 1983, 3-Hodges and Spear, 1982, 4-Ganguly and Saxena, 1984, 5-Indares and Martignole 1985

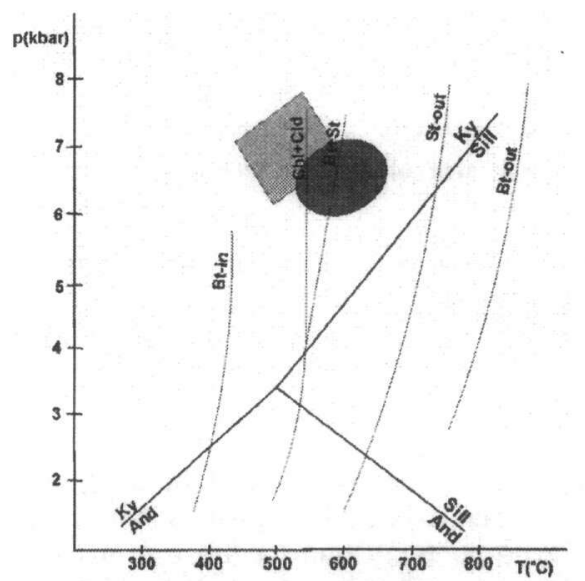

Figure 7. Position of metamorphic assemblages from mica-schist from Crni Vrh (dark gray field) and Resavski Humovi (light gray field)

\section{CONCLUSION}

Textural relationships and petrogenetically significant mineral assemblages in the investigated rocks imply peak P-T conditions of $6-7 \mathrm{kbar}$ and temperatures ranging from $550-600^{\circ} \mathrm{C}$. Calculated P-T conditions agree $w$ th the metamorphic conditions and the P-T path deduced through phase equilibria in pelitic systems (Fig. 7).

The protoliths of mica-schists were the equivalent of a sedimentary unit consisting of mudstone, carbonaceous shale, greywackes, perhaps deposited in epicontinental or intracontinental basin.

Metamorphic assemblages and field observations suggest a complex tectonic history. We identify three generations of minerals based on mineral paragenesis, mineral-fabric relationships and disequilibrium assemblages.

\section{REFERENCES}

Ferry, J.M. and Spear, F.S., 1978: Experimental calibration of the partitioning of Fe and Mg between biotite and garnet, Contribution to Mineralogy and Petrology, 66, 113-117 
Ganguly, J. and Saxena, S.K., 1984: Mixing properties of aluminosilicate garnets: constraints from natural and experimental data, and applications to geothermo-barometry, American Mineralogist, 69, 88-97

Gessmann, C.K., Spiering, B. and Raith, M., 1997: Experimental study of the Fe-Mg exchange between garnet and biotite: Constraints on the mixing behavior and analysis of the cation-exchange mechanisms, American Mineralogist, $V 82,1225-1240$

Hodges, K.V. and Spear, F.S., 1982: Geothermometry, geobarometry and $\mathrm{Al}_{2} \mathrm{SiO}_{5}$ triple point at Mt. Moosilauke, New Hampshire, American Mineralogist, 67, 1118-1134

Hynes, A. and Forest, R.C. 1988: Empirical garnet-muscovite geothermometry in low-grade metapelites, Selwyn Range (Canadian Rockies), Journal of Metamorphic Geology, 6, 297-309

Indares, A. and Martignole, J., 1985: Biotite-garnet geothermometry in granulite facies: the influence of Ti and Al in biotite, American Mineralogist, 70, 272-278

Karamata S. and Krstic B., 1996: Terranes of Serbia and neighbouring area. The formation of the geologic framework of Serbia and adjacent area. Dedicated to Akademik Stevan Karamata. 25-40. Belgrade

Perchuk, L.L. and Lavrentova, I.V., 1983: Experimental investigation on exchange equilibria in the system cordierite-garnet-biotite; In: Kinetics and Equlibria in Mineral Reactions, springer-Verlag, New York, 199-239

Powell, R. and Holland, T.J.B., 1988: An internally consistent thermodynamic dataset with uncertainties and correlations: 3. Applications to geobarometry, Worked examples and a computer program. Journal of Metamorphic Geology, 's, 173-204 